\title{
The Effect of $\mathrm{Ga}_{2} \mathrm{Se}_{3}$ Doping Ratios on Structure, Composition, and Electrical Properties of $\mathrm{CuIn}_{0.5} \mathrm{Ga}_{0.5} \mathrm{Se}_{2}$ Absorber Formed by Thermal Sintering
}

\author{
Chung Ping Liu, ${ }^{1,2}$ Ming Wei Chang, ${ }^{1}$ and Chuan Lung Chuang ${ }^{1}$ \\ ${ }^{1}$ Department of Photonics Engineering, Yuan Ze University, 135 Yuan Tung Road, Chungli 320, Taiwan \\ ${ }^{2}$ Department of Physics, Fu Jen Catholic University, 510 Zhongzheng Road, Xinzhuang District, New Taipei 242, Taiwan \\ Correspondence should be addressed to Chung Ping Liu; eecpliu@saturn.yzu.edu.tw
}

Received 30 August 2013; Revised 15 October 2013; Accepted 16 October 2013

Academic Editor: David Lee Phillips

Copyright ( $\odot 2013$ Chung Ping Liu et al. This is an open access article distributed under the Creative Commons Attribution License, which permits unrestricted use, distribution, and reproduction in any medium, provided the original work is properly cited.

Chalcopyrite compounds of copper indium gallium diselenide (CIGS) absorber were fabricated by using binary-particle $\left(\mathrm{Cu}_{2} \mathrm{Se}\right.$, $\mathrm{In}_{2} \mathrm{Se}_{3}$, and $\mathrm{Ga}_{2} \mathrm{Se}_{3}$ ) precursors with thermal sintering method. The binary-particle ink was firstly prepared by milling technology and then printed onto a soda lime glass substrate, which was baked at a low temperature to remove solvents and form a dry precursor. Following milling, the average particle size of agglomerated CIGS powder is smaller than $1.1 \mu \mathrm{m}$. Crystallographic, stoichiometric, and electrical properties of precursor CIGS films with various doping amounts of $\mathrm{Ga}_{2} \mathrm{Se}_{3}$ had been widely investigated by using thermal sintering in a nonvacuum environment without selenization. Analytical results reveal that the CIGS absorption layer prepared with a $\mathrm{Ga}_{2} \mathrm{Se}_{3}$ doping ratio of 3 has a chalcopyrite structure and favorable composition. The mole ratio of $\mathrm{Cu}: \mathrm{In}: \mathrm{Ga}: \mathrm{Se}$ of this sample was $1.03: 0.49: 0.54: 1.94$, and related ratios of $\mathrm{Ga} /(\mathrm{In}+\mathrm{Ga})$ and $\mathrm{Cu} /(\mathrm{In}+\mathrm{Ga})$ were 0.52 and 0.99 , respectively. The resistivity and carrier concentration were $3.77 \mathrm{ohm}-\mathrm{cm}$ and $1.15 E+18 \mathrm{~cm}^{-3}$.

\section{Introduction}

Chalcopyrite compounds of copper indium gallium diselenide (CIGS) and related alloys are among the most promising materials for photovoltaic applications [1]. CIGS-based solar cells have potential portable applications because of their high absorption coefficient, large absorption spectrum, and high stability. Recent investigations have revealed efficiencies as high as $20.3 \%$ for thin-film CIGS-based solar cells [2].

A set of low-cost approaches with the realistic potential to reduce direct manufacturing costs has been developed in the last five years. Industrial production of CIGS solar cell is mostly based on vacuum processes, which depends on a high initial investment in manufacturing machines. These low-cost techniques typically involve the use of simple and fast nonvacuum deposition methods and the molecular prefixing of the film composition in a precursor layer, which is chemically and thermally treated to form a high-quality CIGS film.
In recent years, CIGS absorbing layers had been fabricated using nanoparticles [3-5] and other coating methods. For nanoparticle-based process, there are two approaches to be used to form the CIGS absorption layer. One is the preparation of a precursor film by synthesizing CIGS powder [3] and the other one is a mechanochemical process (MCP) [4] or a rotary ball milling (RBM) method implemented before nonvacuum coating [5]. For MCP, four elemental metal powders of $\mathrm{Cu}, \mathrm{In}, \mathrm{Ga}$, and Se are mixed and milled by the planetary ball milling technology, yielding a particle size of $1 \mu \mathrm{m}$ after milling [4]. For RBM, the precursor has quaternary compound composition ratios of $\mathrm{Cu} /(\mathrm{In}+\mathrm{Ga})=$ $0.95, \mathrm{Ga} /(\mathrm{In}+\mathrm{Ga})=0.39$, and $\mathrm{Se} /(\mathrm{Cu}+\mathrm{In}+\mathrm{Ga})=0.75$. After milling, the particle size of the agglomerated CIGS powder is less than $100 \mathrm{~nm}$ [5]. Thus, thermal sintering can cause precursor films forming the dense absorption layer for use in solar cells [6]. All steps performed in a nonvacuum environment are relatively simple and inexpensive, such as ease of scalup [7] and excellent control of the ratios of the metal concentrations. To fabricate low-cost and printable 
TABLE 1: Data of CIGS samples sintered at various doping ratios of $\mathrm{Ga}_{2} \mathrm{Se}_{3}$.

\begin{tabular}{|c|c|c|c|c|c|}
\hline \multirow{2}{*}{ Parameter } & \multicolumn{5}{|c|}{ Samples } \\
\hline & CIS & CIGS-1 & CIGS-2 & CIGS-3 & CIGS-4 \\
\hline $\mathrm{Cu}_{2} \mathrm{Se}: \mathrm{In}_{2} \mathrm{Se}_{3}: \mathrm{Ga}_{2} \mathrm{Se}_{3}$ & $1: 5.67: 0$ & $1: 5.67: 1$ & $1: 5.67: 2$ & $1: 5.67: 3$ & $1: 5.67: 4$ \\
\hline $\mathrm{Cu}($ at.\%) & 24.80 & 30.86 & 28.32 & 25.67 & 21.01 \\
\hline In (at.\%) & 25.12 & 16.70 & 15.44 & 12.36 & 10.48 \\
\hline $\mathrm{Ga}($ at. $\%)$ & 0.00 & 4.35 & 7.09 & 13.56 & 17.93 \\
\hline Se (at.\%) & 50.08 & 48.09 & 49.15 & 48.41 & 50.59 \\
\hline Mole ratio of $\mathrm{Cu}$ & 0.99 & 1.23 & 1.13 & 1.03 & 0.84 \\
\hline Mole ratio of In & 1.00 & 0.67 & 0.62 & 0.49 & 0.42 \\
\hline Mole ratio of $\mathrm{Ga}$ & 0.00 & 0.17 & 0.28 & 0.54 & 0.72 \\
\hline Mole ratio of Se & 2.0 & 1.92 & 1.97 & 1.94 & 2.02 \\
\hline $\mathrm{Ga} /(\mathrm{In}+\mathrm{Ga})$ & 0.00 & 0.21 & 0.31 & 0.52 & 0.63 \\
\hline $\mathrm{Cu} /(\mathrm{In}+\mathrm{Ga})$ & 0.99 & 1.47 & 1.26 & 0.99 & 0.74 \\
\hline Resistively (ohm-cm) & 44.8 & 0.408 & 6.89 & 3.77 & 41.8 \\
\hline Carrier concentration $\left(\mathrm{cm}^{-3}\right)$ & $2.44 \mathrm{E}+15$ & $6.25 \mathrm{E}+18$ & $5.64 \mathrm{E}+16$ & $1.15 \mathrm{E}+18$ & $1.66 \mathrm{E}+17$ \\
\hline (112) plane & $26.575^{\circ}$ & $26.675^{\circ}$ & $26.975^{\circ}$ & $27.075^{\circ}$ & $27.175^{\circ}$ \\
\hline$(220) /(204)$ plane & $44.175^{\circ}$ & $44.425^{\circ}$ & $44.725^{\circ}$ & $44.975^{\circ}$ & $45.125^{\circ}$ \\
\hline$(312) /(116)$ plane & $52.325^{\circ}$ & $52.575^{\circ}$ & $53.125^{\circ}$ & $53.325^{\circ}$ & $53.525^{\circ}$ \\
\hline
\end{tabular}

CIGS thin-film solar cells, Lee et al. [8] developed a precursor solution by using a nanoparticle-based method in 2011. In that process, a nearly carbon-free CIGS film can be obtained by applying a three-step heat treatment process: the first step is the elimination of carbon residues by air annealing, the second step is the formation of CIGS alloys by sulfurization, and the third step is the grain growth and the densification of CIGS films by selenization.

This work proposes another process to fabricate a CIGS absorption layer by using binary-particle precursors, such as $\mathrm{Cu}_{2} \mathrm{Se}, \mathrm{In}_{2} \mathrm{Se}_{3}$, and $\mathrm{Ga}_{2} \mathrm{Se}_{3}$, through thermal sintering. Crystallographic, stoichiometric, and electrical properties of $\mathrm{CuIn}_{0.5} \mathrm{Ga}_{0.5} \mathrm{Se}_{2}$ absorber prepared with binary-particle precursors affected by the doping amount of $\mathrm{Ga}_{2} \mathrm{Se}_{3}$ were examined and analyzed through various measurements, such as scanning electron microscopy (SEM), X-ray diffractometry (XRD), energy dispersive spectrometry (EDS), Hall measurement, and thermogravimetry analyzer (TGA). Consequently, an optimized doping amount of the $\mathrm{Ga}_{2} \mathrm{Se}_{3}$ for forming $\mathrm{CuIn}_{0.5} \mathrm{Ga}_{0.5} \mathrm{Se}_{2.0}$ absorption layers could be obtained.

\section{Experiment}

Three binary-alloy powders were mixed with appropriate solvents, whose initial stoichiometric ratios are presented in Table 1. Those powders were then ground into binary-alloy particles by using a mill technology to form the ink that was required for preparing the film precursors. Three commercially available binary-alloy powders of $\mathrm{In}_{2} \mathrm{Se}_{3}, \mathrm{Ga}_{2} \mathrm{Se}_{3}$, and $\mathrm{Cu}_{2}$ Se with grain sizes of approximately $74 \mu \mathrm{m}$ (Williams Advanced Materials Technologies Taiwan Co., Ltd., 99.99\%) were used as starting materials for forming CIGS absorption layers in a nonvacuum environment.

To obtain the ink for forming CIS and CIGS precursor films, three starting materials were mixed with solvent and

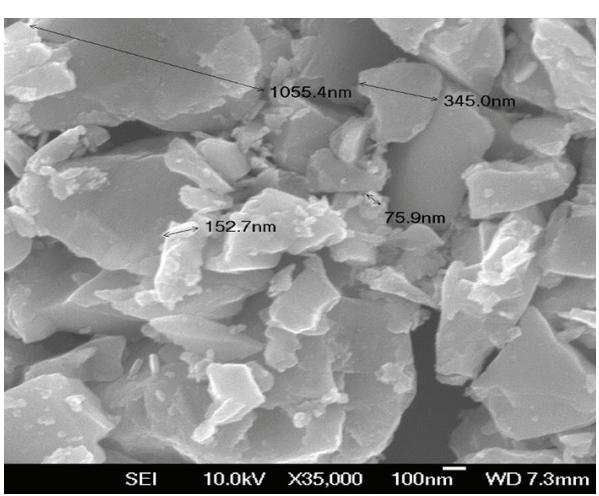

FIGURE 1: SEM photograph. The average grain size of agglomerated CIGS powder after milling is smaller than $1.1 \mu \mathrm{m}$.

zirconium beads; each zirconium bead (diameter: $0.5 \mathrm{~mm}$ and mass: $20 \mathrm{~g}$ ) was ground continuously in a mill for eight hours to produce the required ink. The SEM photograph shows that the average grain size of agglomerated CIGS powders is less than $1.1 \mu \mathrm{m}$, as shown in Figure 1. After the ink printed onto a soda lime glass substrate, the solvent was removed by placing the sample into an oven at a temperature of $120^{\circ} \mathrm{C}$ and maintaining for $5 \mathrm{~min}$. Then, the temperature was increased from 120 to $200^{\circ} \mathrm{C}$ at the same rate and maintained at $200^{\circ} \mathrm{C}$ for $10 \mathrm{~min}$. Once the oven turned off, the expected dry precursor film could be obtained when the sample was cooled down to the room temperature. Subsequently, the $\mathrm{CuIn}_{1-x} \mathrm{Ga}_{x} \mathrm{Se}_{2.0}$ absorption layer for use in solar cells can be formed by thermal sintering.

The weight loss of $\mathrm{Cu}_{2} \mathrm{Se}, \mathrm{In}_{2} \mathrm{Se}_{3}$, and $\mathrm{Ga}_{2} \mathrm{Se}_{3}$ measured by TGA is as shown in Figure 2 . The data shows that the loss of $\mathrm{Cu}_{2} \mathrm{Se}$ is $2 \%$ at $520^{\circ} \mathrm{C}$, whereas the losses of $\mathrm{In}_{2} \mathrm{Se}_{3}$ and $\mathrm{Ga}_{2} \mathrm{Se}_{3}$ are $32.5 \%$ and $25 \%$, respectively, at $420^{\circ} \mathrm{C}$. Based on these data, the sintering temperature was set at 


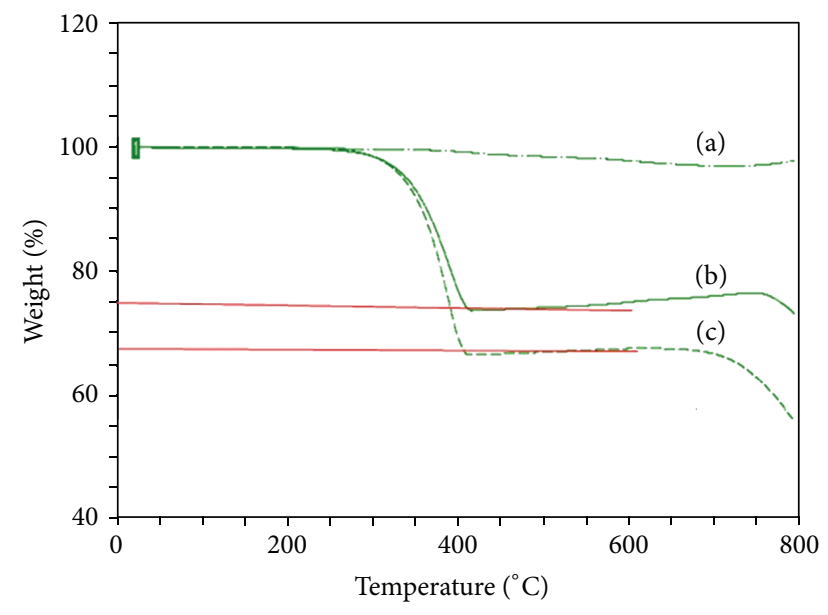
(a) $\mathrm{Cu}_{2} \mathrm{Se}$
(b) $\mathrm{Ga}_{2} \mathrm{Se}_{3}$
(c) $\mathrm{In}_{2} \mathrm{Se}_{3}$

Figure 2: TGA data for weight losses of $\mathrm{Cu}_{2} \mathrm{Se}, \mathrm{In}_{2} \mathrm{Se}_{3}$, and $\mathrm{Ga}_{2} \mathrm{Se}_{3}$.

$420^{\circ} \mathrm{C}$ and maintained for $30 \mathrm{~min}$; then the temperature was increasing from 420 to $520^{\circ} \mathrm{C}$ and maintained at $520^{\circ} \mathrm{C}$ for one hour. Subsequently, prepared precursor samples were heated in a thermal annealing furnace filled with nitrogen. Thus, $\mathrm{CuIn}_{1-x} \mathrm{Ga}_{x} \mathrm{Se}_{2.0}$ films with highly uniform crystalline structure could be formed. After one hour, the temperature was dropped below $50^{\circ} \mathrm{C}$. Since the amount of $\mathrm{Ga}_{2} \mathrm{Se}_{3}$ can affect the film structure of $\mathrm{CuIn}_{1-x} \mathrm{Ga}_{x} \mathrm{Se}_{2.0}$ sample, the properties of the sample can be analyzed according to this point.

\section{Results and Discussion}

3.1. Structural Properties. Figure 3 presents the XRD patterns of samples that were sintered with various amounts of $\mathrm{Ga}_{2} \mathrm{Se}_{3}$. The XRD measurement was executed by scanning the diffraction angle from 20 to $60^{\circ}$ and using a grazing incidence angle of $1^{\circ}$. In Figure 3, XRD patterns display that sintered CIGS samples have many diffraction peaks at (112), (220)/(204), and (312)/(116), corresponding to different crystalline structures, respectively.

From sample CIS to sample CIGS-4, the XRD peak at (112) shifts from 2-theta $=26.575^{\circ}$ to 2-theta $=27.175^{\circ}$. According to the results reported by Balboul et al. [9], the compositions were determined by calculating the peak shift with the ratio of In: Ga. As Ga content increases, the doublet of peaks, that is, $(220) /(204)$ peak and (116)/(312) peak, is splitting into two individual parts. This splitting indicates that the deviation of tetragonality, that is, $c / a=2$, was resulted by Ga substitution. These results are ascribed to the small ionic size of $\mathrm{Ga}, 0.62 \AA$, compared to that of In, $0.81 \AA$. As $\mathrm{Ga}_{2} \mathrm{Se}_{3}$ ratio increases, all signals shift towards larger diffraction angles. Figure 3 shows this effect on the signal of (112). This noticeable shift is due to the decrease in lattice constants " $a$ " and " $c$ " as reported by Olejníček et al. [10]. The chalcopyrite structure of $\mathrm{CuIn}_{0.5} \mathrm{Ga}_{0.5} \mathrm{Se}_{2.0}$ was modeled using the space

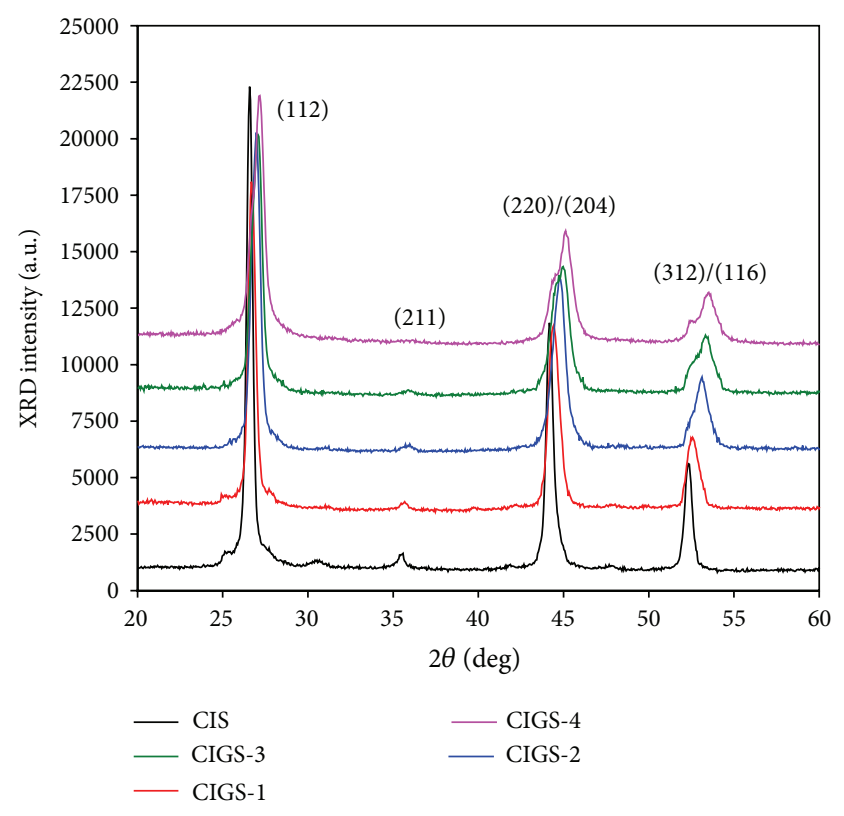

FIGURE 3: XRD patterns of sintered samples with various doping amounts of $\mathrm{Ga}_{2} \mathrm{Se}_{3}$.

group I42d (122) with standard lattice constants of $a=5.673 \AA$ and $c=11.322 \AA$ (JCPDS-40-1488) [11, 12]. Table 1 and Figure 3 reveal that the 2-theta data of the sintered sample with a $\mathrm{Ga}_{2} \mathrm{Se}_{3}$ doping ratio of 3 (CIGS-3) are very close to those on the JCPDS card (40-1488) for $\mathrm{Cu}\left(\mathrm{Ga}_{0.5} \mathrm{In}_{0.5}\right) \mathrm{Se}_{2.0}$ at the angles of $27.075^{\circ}, 44.975^{\circ}$, and $53.325^{\circ}$, respectively.

3.2. Compositions. The stoichiometric compositions of CIGS samples having various $\mathrm{Ga}_{2} \mathrm{Se}_{3}$ doping ratios were analyzed by using EDS data, as shown in Table 1. An attempt was also made to optimize the $\mathrm{Cu}$, In, Ga, and Se contents in the CIGS absorption layer of solar cells. The $\mathrm{Ga} /(\mathrm{In}+\mathrm{Ga})$ and $\mathrm{Cu} /(\mathrm{In}+\mathrm{Ga})$ mole ratios presented in Table 1 were obtained by using various $\mathrm{Ga}_{2} \mathrm{Se}_{3}$ doping ratios. For samples sintered with various $\mathrm{Ga}_{2} \mathrm{Se}_{3}$ doping ratios, their ratios of $\mathrm{Ga} /(\mathrm{In}+$ $\mathrm{Ga})$ and $\mathrm{Cu} /(\mathrm{In}+\mathrm{Ga})$ are shown in Figure 4. Since the mole ratios of $\mathrm{Ga} /(\mathrm{In}+\mathrm{Ga})$ and $\mathrm{Cu} /(\mathrm{In}+\mathrm{Ga})$, respectively, are 0.52 and 0.99 , the doping ratio of $\mathrm{Ga}_{2} \mathrm{Se}_{3}$ for CIGS-3 sample is the optimal. For this sample, its doping ratio of $\mathrm{Ga}_{2} \mathrm{Se}_{3}$ is 3 . This reveals that the $\mathrm{Cu}: \mathrm{In}: \mathrm{Ga}$ : Se mole ratio of CIGS-3 is $1.03: 0.49: 0.54: 1.94$, which is approximately $1: 0.5: 0.5: 2.0$ reported elsewhere [13]. For fixed $\mathrm{Cu}$ content, the $\mathrm{Ga} /(\mathrm{In}+$ $\mathrm{Ga})$ ratio and the 2-theta at (112)-peak of each sintered sample corresponding to various $\mathrm{Ga}_{2} \mathrm{Se}_{3}$ doping ratios are shown in Figure 5. Furthermore, the main XRD peaks (112) shown in Figure 3 display a noticeable shift that the higher the angle, the larger the doping ratio of $\mathrm{Ga}_{2} \mathrm{Se}_{3}$, which has also been reported elsewhere [14-17]. This is attributed to relatively small $\mathrm{Ga}$ atoms substituting for larger In atoms in the chalcopyrite structure [17], resulting in a decrease in the lattice parameter.

3.3. Electrical Properties. Parameters related to electrical, structural, and compositional properties of each CIGS sample 


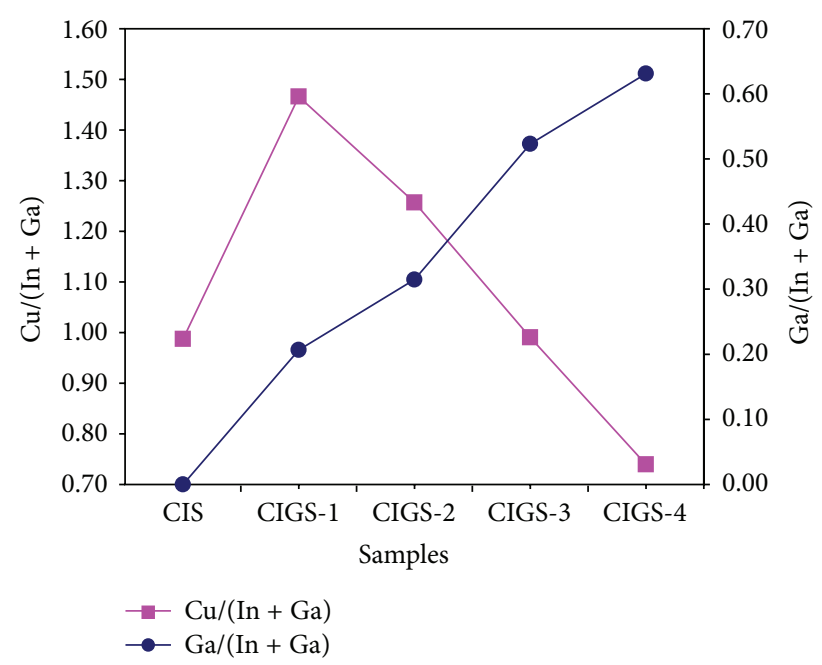

FIgURE 4: $\mathrm{Ga} /(\mathrm{In}+\mathrm{Ga})$ and $\mathrm{Cu} /(\mathrm{In}+\mathrm{Ga})$ ratios of each sintered sample.

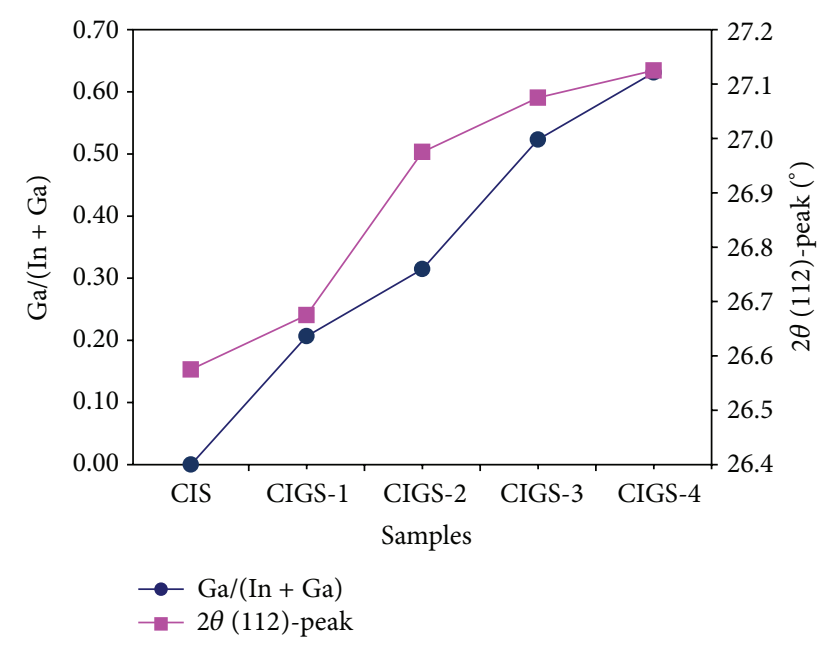

Figure 5: The Ga/(In + Ga) ratio and the 2-theta at (112)-peak of each sintered sample corresponded to various $\mathrm{Ga}_{2} \mathrm{Se}_{3}$ doping ratios.

are listed in Table 1 . The carrier concentration and the electrical resistivity of all sintered CIGS samples were determined by Hall measurement [18], as shown in Figure 6. Measuring data shows that all samples are p-type. At room temperature, each sample has an electrical resistivity between 0.408 and $44.8 \mathrm{ohm}-\mathrm{cm}$ and an associated carrier concentration from $2.44 \mathrm{E}+15$ to $6.25 \mathrm{E}+18 \mathrm{~cm}^{-3}$. The CIGS-1 sample has the lowest resistivity of $0.408 \mathrm{ohm}-\mathrm{cm}$ and the highest carrier concentration of $6.25 \mathrm{E}+18 \mathrm{~cm}^{-3}$. The CIS sample has the highest resistivity of $44.8 \mathrm{ohm}-\mathrm{cm}$ and the lowest carrier concentration of $2.44 \mathrm{E}+15 \mathrm{~cm}^{-3}$. For specified Ga content, Figures 7 and 8 , respectively, show the ratios of $\mathrm{Cu} /(\mathrm{In}+$ $\mathrm{Ga})$ and $\mathrm{Ga} /(\mathrm{In}+\mathrm{Ga})$ of each sintered sample and their related resistivity and carrier concentration. These two figures reveal that CIGS-1 had the highest ratio of $\mathrm{Cu} /(\mathrm{In}+\mathrm{Ga})$, the lowest resistivity of $0.408 \mathrm{ohm}-\mathrm{cm}$, and the highest carrier concentration of $6.25 \mathrm{E}+18 \mathrm{~cm}^{-3}$. Sample CIGS-4 has a lower

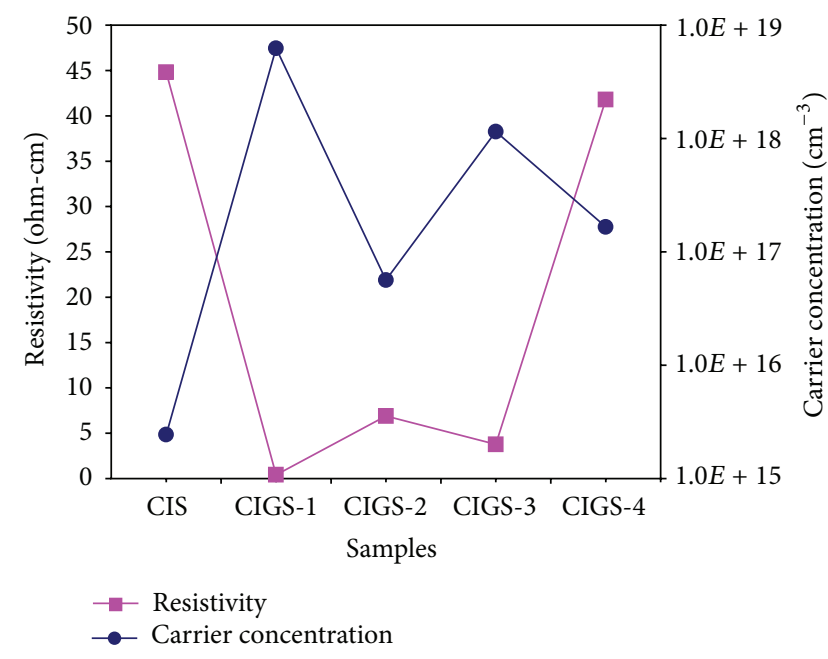

FIGURE 6: The resistivity and carrier concentration of each sintered sample.

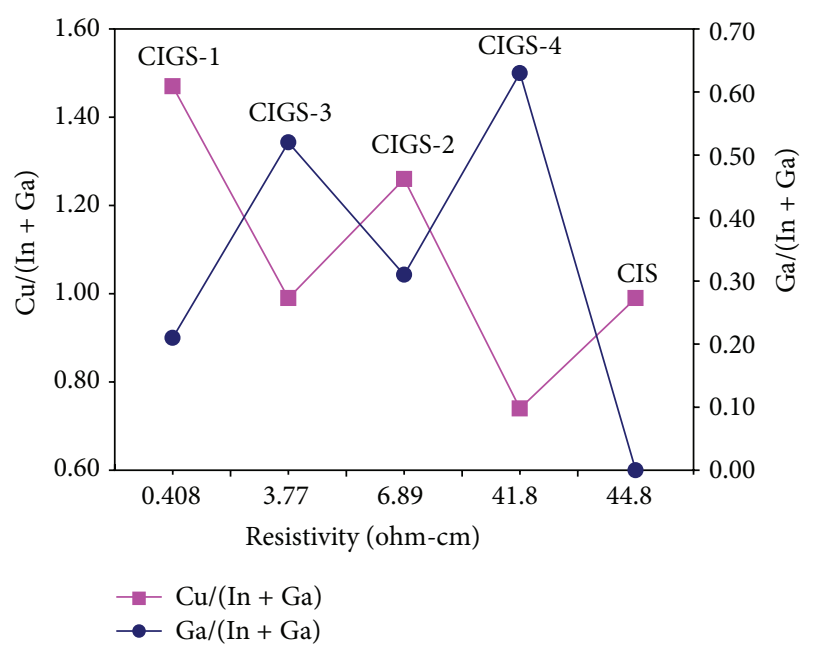

Figure 7: The $\mathrm{Cu} /(\mathrm{In}+\mathrm{Ga})$ and $\mathrm{Ga} /(\mathrm{In}+\mathrm{Ga})$ ratios and resistivity of each sintered sample.

ratio of $\mathrm{Cu} /(\mathrm{In}+\mathrm{Ga})$ and a higher ratio of $\mathrm{Ga} /(\mathrm{In}+\mathrm{Ga})$, as well as the highest resistivity of $41.8 \mathrm{ohm}-\mathrm{cm}$ and a carrier concentration of $1.66 \mathrm{E}+17 \mathrm{~cm}^{-3}$. For sample CIGS-3, however, its resistivity and carrier concentration are $3.77 \mathrm{ohm}-\mathrm{cm}$ and $1.15 \mathrm{E}+18 \mathrm{~cm}^{-3}$, respectively. Moreover, according to the pieces of literature reported by Turcu and Rau and Zhang et al. $[19,20]$, the $\mathrm{Cu}$-rich films phase has lower electrical resistivity and higher carrier concentration, whereas the $\mathrm{Cu}$ poor films phase has higher electrical resistivity and lower carrier concentration.

Based on the data shown in Section 3.2, the ratio of $\mathrm{Cu} /(\mathrm{In}+\mathrm{Ga})$ of the sample CIGS-3 is nearly equal to one, so that it is very suitable for the $\mathrm{CuIn}_{1-x} \mathrm{Ga}_{x} \mathrm{Se}_{2.0}$ absorbing layer having the required resistivity and carrier concentration [21-26]. For this sample, the ratios of $\mathrm{Cu} /(\mathrm{In}+\mathrm{Ga})=0.99$ and $\mathrm{Ga} /(\mathrm{In}+\mathrm{Ga})=0.52$ were optimal because the mole ratio of $\mathrm{Cu}: \mathrm{In}: \mathrm{Ga}: \mathrm{Se}$ is very close to the expected value 


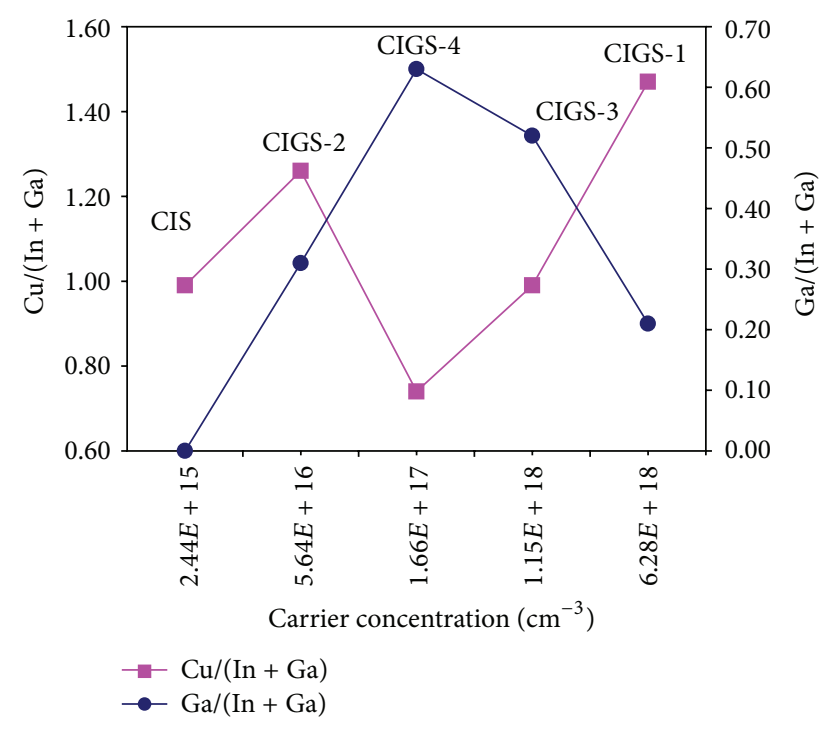

Figure 8: The $\mathrm{Cu} /(\mathrm{In}+\mathrm{Ga})$ and $\mathrm{Ga} /(\mathrm{In}+\mathrm{Ga})$ ratios and carrier concentration of each sintered sample.

of $1: 0.5: 0.5: 2.0$ [13]. At the same time, the 2-theta data of CIGS-3 is also close to that on the JCPDS card (40-1488) for $\mathrm{Cu}\left(\mathrm{Ga}_{0.5} \mathrm{In}_{0.5}\right) \mathrm{Se}_{2.0}$. Additionally, the data of 2-theta at the peak of (112) increases with the doping amount of $\mathrm{Ga}_{2} \mathrm{Se}_{3}$. This is consistent with the result reported by other several works [14-17].

\section{Conclusions}

In this paper, a CIGS absorber prepared by using binaryparticle $\left(\mathrm{Cu}_{2} \mathrm{Se}, \mathrm{In}_{2} \mathrm{Se}_{3}, \mathrm{Ga}_{2} \mathrm{Se}_{3}\right)$ precursors via thermal sintering method had widely been investigated. The required binary-particle ink for fabricating the absorbing layer was prepared by using the milling technology. The SEM photograph reveals that the average particle size of the agglomerated CIGS powder is smaller than $1.1 \mu \mathrm{m}$ after milling. Analytical results obtained from measurements of SEM, XRD, EDS, Hall, and TGA reveal that the CIGS-3 sample has a chalcopyrite structure and a favorable composition of $\mathrm{CuIn}_{0.5} \mathrm{Ga}_{0.5} \mathrm{Se}_{2.0}$. The $\mathrm{Cu}$ : In : $\mathrm{Ga}$ : Se mole ratio of CIGS-3 is $1.03: 0.49: 0.54: 1.94$, and its resistivity and carrier concentration are $3.77 \mathrm{ohm}-\mathrm{cm}$ and $1.15 \mathrm{E}+18 \mathrm{~cm}^{-3}$, respectively. Among those sintered samples prepared in our laboratory, the 2-theta data of CIGS-3 is very close to the data on the JCPDS card (40-1488) for $\mathrm{Cu}\left(\mathrm{Ga}_{0.5} \mathrm{In}_{0.5}\right) \mathrm{Se}_{2.0}$. In summary, our investigations mainly focused on crystallographic, stoichiometric, and electrical properties of $\mathrm{CuIn}_{0.5} \mathrm{Ga}_{0.5} \mathrm{Se}_{2.0}$ thin film and obtained the optimized doping amount of $\mathrm{Ga}_{2} \mathrm{Se}_{3}$ in a CIGS absorbing layer.

\section{Conflict of Interests}

All authors declare that there is no conflict of interests regarding the publication of this paper.

\section{Acknowledgment}

The authors would like to thank the National Science Council, Taiwan, for financially supporting this research under Contracts nos. NSC 99-2221-E-155-051 and NSC 100-2221-E-155045 .

\section{References}

[1] T. M. Razykov, C. S. Ferekides, D. Morel, E. Stefanakos, H. S. Ullal, and H. M. Upadhyaya, "Solar photovoltaic electricity: current status and future prospects," Solar Energy, vol. 85, no. 8, pp. 1580-1608, 2011.

[2] P. Jackson, D. Hariskos, E. Lotter et al., "New world record efficiency for $\mathrm{Cu}(\mathrm{In}, \mathrm{Ga}) \mathrm{Se}_{2}$ thin-film solar cells beyond $20 \%$," Progress in Photovoltaics, vol. 19, no. 7, pp. 894-897, 2011.

[3] E. Lee, J. W. Cho, J. Kim, J. Yun, J. H. Kim, and B. K. Min, "Synthesis of CIGS powders: transition from binary to quaternary crystalline structure," Journal of Alloys and Compounds, vol. 506, no. 2, pp. 969-972, 2010.

[4] T. Wada, Y. Matsuo, S. Nomura et al., "Fabrication of $\mathrm{Cu}$ (In, $\mathrm{Ga}) \mathrm{Se}_{2}$ thin films by a combination of mechanochemical and screen-printing/sintering processes," Physica Status Solidi A, vol. 203, no. 11, pp. 2593-2597, 2006.

[5] C. P. Liu and C. L. Chuang, "Fabrication of copper-indium-gallium-diselenide absorber layer by quaternary-alloy nanoparticles for solar cell applications," Solar Energy, vol. 86, no. 9, pp. 2795-2801, 2012.

[6] S. J. Ahn, C. Kim, J. Yun, J. Lee, and K. Yoon, "Effects of heat treatments on the properties of $\mathrm{Cu}(\mathrm{In}, \mathrm{Ga}) \mathrm{Se}_{2}$ nanoparticles," Solar Energy Materials and Solar Cells, vol. 91, no. 19, pp. 18361841, 2007.

[7] S. Yoon, T. Yoon, K.-S. Lee, S. Yoon, J. M. Ha, and S. Choe, "Nanoparticle-based approach for the formation of CIS solar cells," Solar Energy Materials and Solar Cells, vol. 93, no. 6-7, pp. 783-788, 2009.

[8] E. Lee, S. J. Park, J. W. Cho, J. Gwak, M.-K. Oh, and B. K. Min, "Nearly carbon-free printable CIGS thin films for solar cell applications," Solar Energy Materials and Solar Cells, vol. 95, no. 10, pp. 2928-2932, 2011.

[9] M. R. Balboul, H. W. Schock, S. A. Fayak, A. Abdel El-Aal, J. H. Werner, and A. A. Ramadan, "Correlation of structure parameters of absorber layer with efficiency of $\mathrm{Cu}(\mathrm{In}, \mathrm{Ga}) \mathrm{Se}_{2}$ solar cell," Applied Physics A, vol. 92, no. 3, pp. 557-563, 2008.

[10] J. Olejníček, C. A. Kamler, A. Mirasano et al., "A non-vacuum process for preparing nanocrystalline $\mathrm{CuIn}_{1-x} \mathrm{Ga}_{x} \mathrm{Se}_{2}$ materials involving an open-air solvothermal reaction," Solar Energy Materials and Solar Cells, vol. 94, no. 1, pp. 8-11, 2010.

[11] B. Vidhya, S. Velumani, J. A. Arenas-Alatorre, A. Morales-Acevedo, R. Asomoza, and J. A. Chavez-Carvayar, "Structural studies of mechano-chemically synthesized $\mathrm{CuIn}_{1-x} \mathrm{Ga}_{x} \mathrm{Se}_{2}$ nanoparticles," Materials Science and Engineering B, vol. 174, no. 1-3, pp. 216-221, 2010.

[12] D. Suri, K. Nagpal, and G. Chadha, "X-ray study of $\mathrm{CuGa}_{x} \mathrm{In}_{1-x} \mathrm{Se}_{2}$ solid solutions," Journal of Applied Crystallography, vol. 22, pp. 578-583, 1989.

[13] E. Yassitepe, Z. Khalifa, G. H. Jaffari et al., "A new route for the synthesis of $\mathrm{CuIn}{ }_{0.5} \mathrm{Ga}_{0.5} \mathrm{Se}_{2}$ powder for solar cell applications," Powder Technology, vol. 201, no. 1, pp. 27-31, 2010.

[14] S. Jung, S. Ahn, J. H. Yun, J. Gwak, D. Kim, and K. Yoon, "Effects of Ga contents on properties of CIGS thin films and solar 
cells fabricated by co-evaporation technique," Current Applied Physics, vol. 10, no. 4, pp. 990-996, 2010.

[15] H. Miyazaki, R. Mikami, A. Yamada, and M. Konagai, " $\mathrm{Cu}(\mathrm{InGa}) \mathrm{Se}_{2}$ thin film absorber with high $\mathrm{Ga}$ contents and its application to the solar cells," Journal of Physics and Chemistry of Solids, vol. 64, no. 9-10, pp. 2055-2058, 2003.

[16] Y.-H. A. Wang, C. Pan, N. Bao, and A. Gupta, "Synthesis of ternary and quaternary $\mathrm{Culn}_{x} \mathrm{Ga}_{1-x} \mathrm{Se}_{2}(0 \leq x \leq 1)$ semiconductor nanocrystals," Solid State Sciences, vol. 11, no. 11, pp. 19611964, 2009.

[17] W. N. Shafarman, R. Klenk, and B. E. McCandless, "Device and material characterization of $\mathrm{Cu}(\mathrm{InGa}) \mathrm{Se}_{2}$ solar cells with increasing band gap," Journal of Applied Physics, vol. 79, no. 9, pp. 7324-7328, 1996.

[18] L. J. van der Pauw, "A method of measuring specific resistivity and Hall effect of discs of arbitrary shape," Philips Research Reports, vol. 13, pp. 1-9, 1958.

[19] M. Turcu and U. Rau, "Compositional trends of defect energies, band alignments, and recombination mechanisms in the $\mathrm{Cu}(\mathrm{In}, \mathrm{Ga})(\mathrm{Se}, \mathrm{S})_{2}$ alloy system," Thin Solid Films, vol. 431-432, pp. 158-162, 2003.

[20] L. Zhang, F.-F. Liu, F.-Y. Li, Q. He, B.-Z. Li, and C.-J. Li, "Structural, optical and electrical properties of low-temperature deposition $\mathrm{Cu}\left(\mathrm{In}_{x} \mathrm{Ga}_{1-x}\right) \mathrm{Se}_{2}$ thin films," Solar Energy Materials and Solar Cells, vol. 99, pp. 356-361, 2012.

[21] R. R. Philip, B. Pradeep, G. S. Okram, and Y. Ganesan, "Investigations of the electrical properties in $\mathrm{CuInSe}_{2}$ and the related ordered vacancy compounds," Semiconductor Science and Technology, vol. 19, no. 7, pp. 798-806, 2004.

[22] R. D. L. Kristensen, S. N. Sahu, and D. Haneman, "Flash eva-

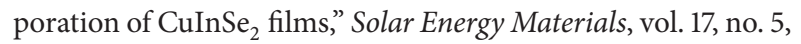
pp. 329-345, 1988.

[23] X. Wang, S. S. Li, C. H. Huang et al., "Investigation of pulsed non-melt laser annealing on the film properties and performance of $\mathrm{Cu}(\mathrm{In}, \mathrm{Ga}) \mathrm{Se}_{2}$ solar cells," Solar Energy Materials and Solar Cells, vol. 88, no. 1, pp. 65-73, 2005.

[24] X. Donglin, X. Man, L. Jianzhuang, and Z. Xiujian, "Coelectrodeposition and Characterization of $\mathrm{Cu}(\mathrm{In}, \mathrm{Ga}) \mathrm{Se}_{2}$ thin films," Journal of Materials Science, vol. 41, no. 7, pp. 1875-1878, 2006.

[25] K. Yoshino, K. Nomoto, A. Kinoshita, T. Ikari, Y. Akaki, and T. Yoshitake, "Dependence of $\mathrm{Cu} / \mathrm{In}$ ratio of structural and electrical characterization of $\mathrm{CuInS}_{2}$ crystal," Journal of Materials Science, vol. 19, no. 4, pp. 301-304, 2008.

[26] A. N. Tiwari, D. K. Pandya, and K. L. Chopra, "Electrical and optical properties of single-phase $\mathrm{CuInS}_{2}$ films prepared using spray pyrolysis," Thin Solid Films, vol. 130, no. 3-4, pp. 217-230, 1985. 

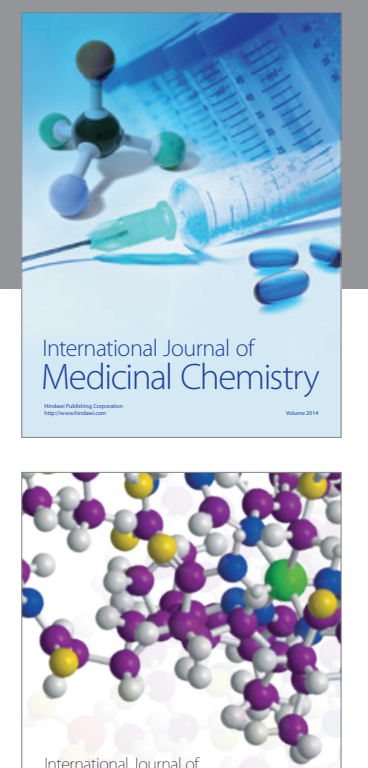

\section{Carbohydrate} Chemistry

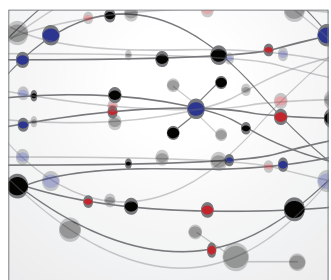

The Scientific World Journal
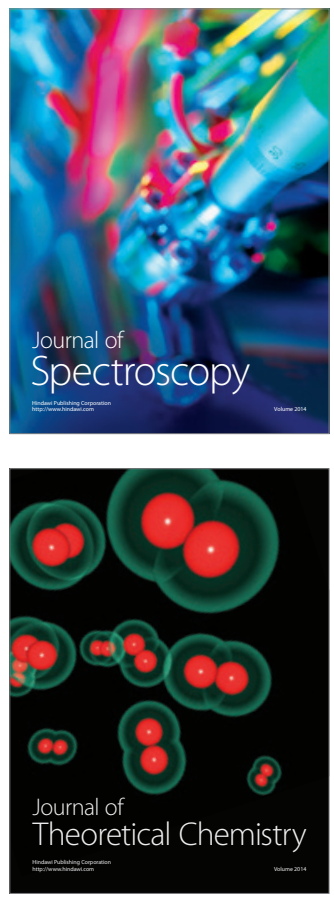
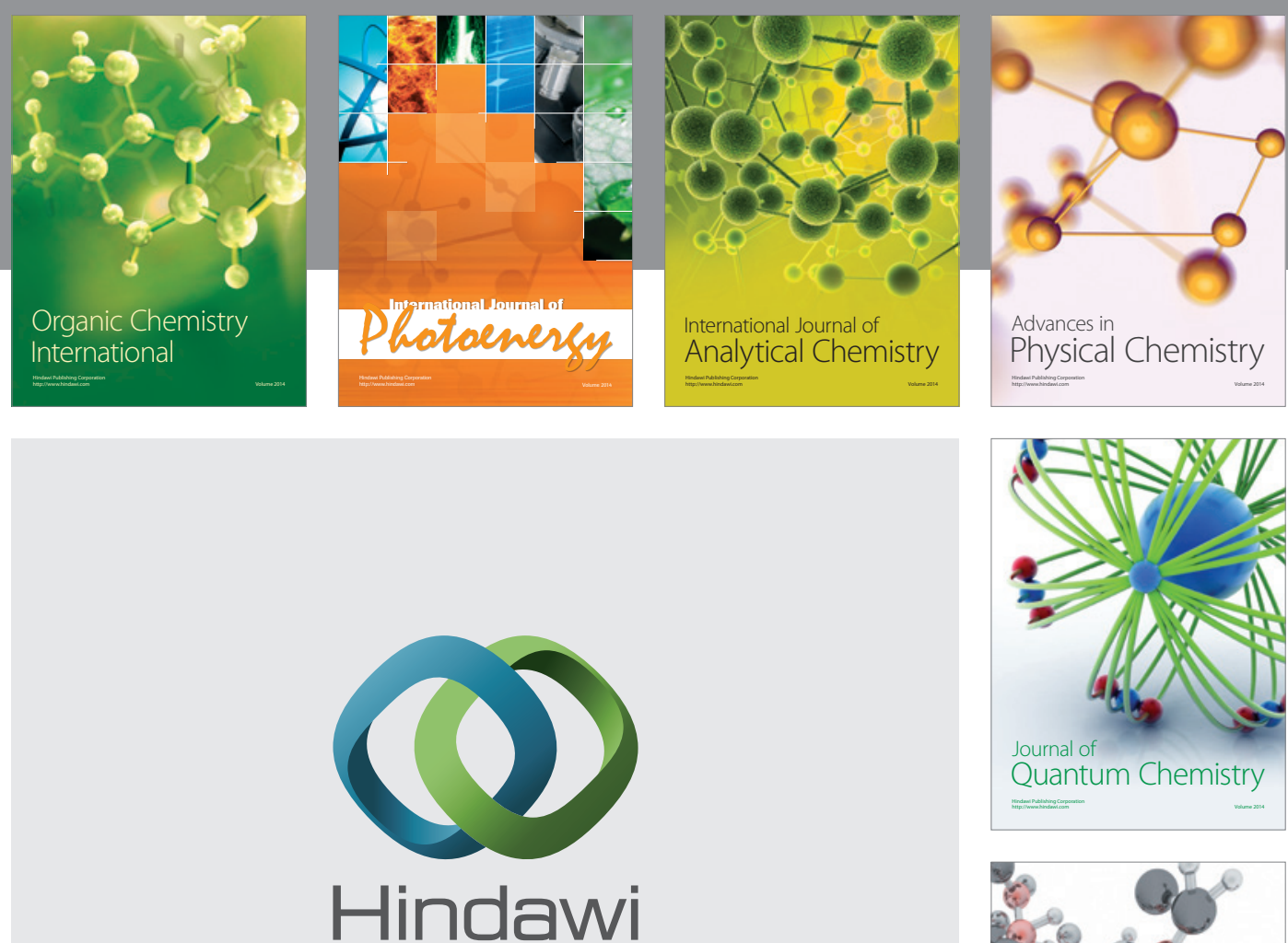

Submit your manuscripts at

http://www.hindawi.com

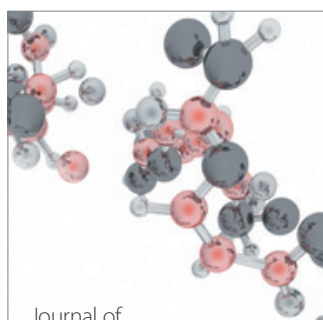

Analytical Methods

in Chemistry

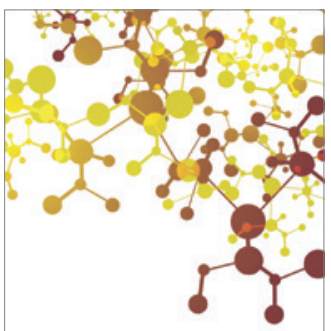

Journal of

Applied Chemistry

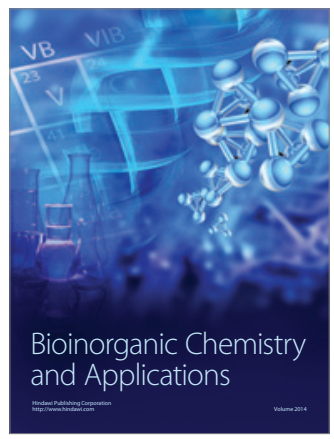

Inorganic Chemistry
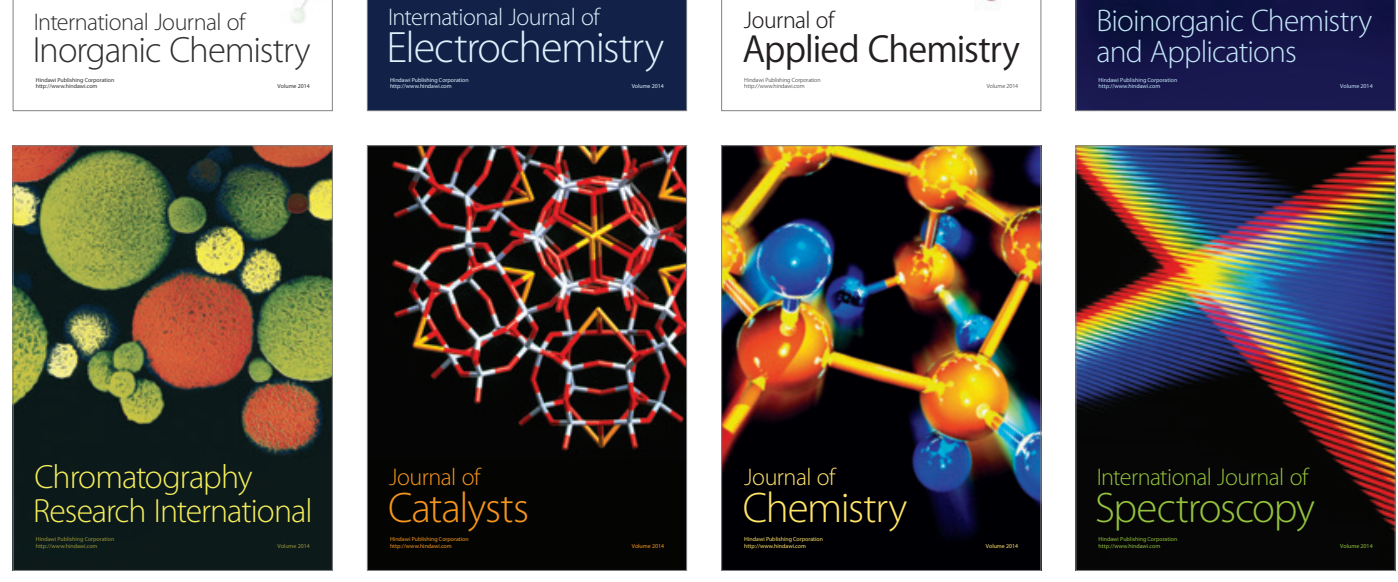